\title{
EVALUASI KUALITAS LAYANAN WEBSITE SIMANTA PKN UNIVERSITAS MUHAMMADIYAH MALANG DENGAN PENDEKATAN WEBQUAL 4.0 DAN ANALISIS IPA
}

\author{
Yasina Tisha Karina', Wahyu Andhyka ${ }^{1}{ }^{2}$ \\ Teknik Informatika, Fakultas Teknik \\ Universitas Muhammadiyah Malang, Malang, Indonesia \\ e-mail : ${ }^{1}$ yasinacaca@gmail.com, ${ }^{2}$ kusuma.wahyu.a@gmail.com \\ Diterima: 18 April 2018. Disetujui : 15 Juni 2018. Dipublikasikan : 29 Juni 2018 \\ (C)2018 -TESJ Fakultas Teknik Universitas Maarif Hasyim Latif. Ini adalah artikel dengan \\ akses terbuka di bawah lisensi CC BY 4.0 (https://creativecommons.org/licenses/by/4.0/)
}

\begin{abstract}
ABSTRAK
Universitas Muhammadiyah Malang (UMM) adalah salah satu dari sekian banyak perguruan tinggi swasta di Indonesia yang terletak di Malang, Jawa Timur. UMM berdiri sejak 1964 dengan banyak prodi yang ada. Seiring dengan perkembangan teknologi, UMM telah banyak melakukan pembangunan dalam bidang teknologi informasi dan komunikasi. Salah satu jurusan yang memanfaatkan teknologi informasi dan komunikasi tersebut yaitu Jurusan Teknik Informatika. Teknik informatika memiliki sebuah website yang bernama SIMANTA PKN UMM guna menunjang aktivitas PKN Mahasiswa dan juga aktivitas bimbingan PKN pasca pelaksanaan. Untuk menilai kualitas dari website tersebut dibutuhkan sebuah metode analisa website yaitu Webqual 4.0 dengan analisa perbaikan berdasarkan kinerja website dan kebutuhan pengguna menggunakan metode analisa IPA. Dari penelitian yang ada, ditemukan atribut-atribut apa saja yang perlu dilakukan perbaikan sesuai dengan kebutuhan pengguna website yaitu mahasiswa Teknik Informatika yang penah mengakses website tersebut. Hasil dari penelitian ini menggambarkan bagaimana kualitas layanan website dan memberikan saran perbaikan website berdasarkan penelitian yang telah dilakukan.
\end{abstract}

Kata kunci: importance performance analysis, teknik komputer, website, webqual

\section{PENDAHULUAN}

Website merupakan bagian penting dari pertumbuhan teknologi informasi. Keberadaan situs web menjadi sangat penting karena berfungsi sebagai penyampai informasi yang dapat diakses selama 24 jam. Peranan website sangatlah penting dalam segala bidang Khususnya untuk sebuah instansi atau organisasi (Christian \& Jaya, 2017). Begitu pula sebuah universitas. Berkembangnya sebuah universitas dapat dipengaruhi juga dengan kualitas website yang baik. Sudah banyak universitas di Indonesia yang mengembang website universitasnnya sebagai langkah untuk memperluas informasi yang ada dalam instansi ke masyarakat sehingga universitas bisa lebih dikenal oleh masyarakat luas.

Menurut informasi pada website universitas, Universitas Muhammadiyah Malang merupakan perguruan tinggi swasta di Indonesia yang terletak di Malang, Jawa Timur. UMM berdiri sejak 1964 dengan berbagai macam bidang studi membuat UMM harus membangun berbagai website guna meningkatkan pelayanan mahasiswa di tiap program studi/jurusan yang ada. Salah satu jurusan yang memanfaatkan teknologi informasi dan komunikasi berbasis website yaitu Jurusan Teknik Informatika.

SIMANTA PKN UMM merupakan satu dari beberapa website yang ada pada Jurusan Teknik Informatika. SIMANTA PKN mulai dikenalkan dan beroperasi pada 2 Februari 2015. Website ini dibangun guna menunjang aktivitas PKN Mahasiswa dan juga aktivitas bimbingan PKN pasca pelaksanaan. Prosedur yang ada pada SIM PKN ini berpegang pada alur pelaksanaan PKN sesungguhnya, sehingga sistem dapat sejalan dan sesuai dengan kebutuhan mahasiswa, dosen dan stakeholder yang ada di lingkup jurusan maupun universitas. Menurut beberapa pengalaman pengguna, website SIMANTA UMM masih memiliki kekuranngan dan perlu dilakukan evaluasi guna melakukan perbaikan kualitas website sebagai upaya peningkatan layanan mahasiswa di Jurusan Teknik Informatika.

Berdasarkan penjelasan tersebut, maka diperlukan sebuah evaluasi kualitas website SIMANTA PKN UMM agar lebih menunjang pelayanan mahasiswa Teknik Informatika sehingga mencapai sebuah kepuasan yang diinginkan oleh mahasiswa. Evaluasi dilakukan untuk menyelaraskan keinginan mahasiswa Teknik 
Informatika dengan website yang telah dibangun. Untuk mengetahui kualitas dan kebergunaan suatu website dalam memenuhi pelayanan pengguna maka dapat dilakukan analisa kualitas layanan website dengan menggunakan skala dimensi Webqual 4.0 .

Webqual merupakan metode untuk pengukuran kualitas website berdasarkan pada persepsi pengguna akhir. Metode webqual 4.0 memiliki tiga dimensi yaitu dimensi kualitas informasi, dimensi kualitas interaksi, dimensi kualitas usability (Baiti, Suprapto, \& Rachmadi, 2017; Christian \& Jaya, 2017). Webqual 4.0 menekankan pada kegunaan (kemudahan penggunaan, navigasi, gambar yang dikirimkan ke pengguna, dll.), kualitas informasi (kualitas layanan yang disampaikan kepada pengguna), interaksi layanan (interaksi layanan yang disediakan di situs web (Kadar, Napitupulu, \& Jati, 2017). Nantinya kuisioner akan disusun berdasarkan tiga dimensi webqual 4.0. Hasilnya akan dianalisis dengan metode Importance Performance Analysis .

Importance Performance Analysis (IPA) adalah metode untuk mengukur kepuasan pengguna terhadap sebuah barang atau jasa yang ditawarkan. Pendekatan IPA didasari oleh kepentingan atau harapan (importance) dan kinerja (perfonrmance) pada produk atau jasa yang ada (Wahyudi, Pinandito, \& Saputra, 2017). Hasil analisa dari menggunakan metode ini akan dibagi menjadi diagram kartesius dengan 4 kuadran yaitu kuadran A (concentrate here), kuadran B (keep up the good work), kuadran C (low priority), dan kuadran D (possible overkill) dan sumbu $x$ serta sumbu $y$. Sumbu $x$ pada diagram merepresentasikan tingkat kinerja dan sumbu $y$ merepresentasikan tingkat kepentingan (Saputra, Suprapto, \& Rachmadi, 2018).

Berdasarkan permasalahan di atas maka perlu diadakan upaya evaluasi website SIMANTA PKN UMM dengan melakukan analisis penilaian dari kualitas layanan website dari sisi pengguna. Analisis ini menggunakan metode webqual 4.0 dan analisis IPA dengan hasil yang akan menggambarkan kualitas layanan website dan memberikan saran perbaikan website berdasarkan penelitian yang telah dilakukan.

\section{METODE PENELITIAN}

\section{Webqual 4.0}

Webqual merupakan metode pengukuran kualitas website yang berdasarkan pada persepsi pengguna akhir. Webqual 4.0 disusun berdasarkan tiga area utama yaitu kualitas informasi, kualitas interaksi dan usability. (Barnes \& Vidgen, 2003) mendefinisikannya sebagai berikut (Baiti et al., 2017; Napitupulu, 2017) :

1. Kualitas informasi

Kualitas informasi meliputi informasi yang akurat, informasi yang dapat dipercaya, informasi yang up to date, informasi sesuai dengan topik bahasan, kemudahan informasi untuk dimengerti, kedetailan informasi dan informasi yang disajikan dalam format desain yang sesuai.

2. Kualitas interaksi

Kualitas interaksi meliputi kemampuan memberikan rasa aman saat melakukan transaksi, memliki reputasi yang bagus, memperlancar komunikasi, menciptakan serta membangun perasaan emosional yang lebih personal, memiliki kepercayaan dalam memberikan informasi pribadi, mampu menciptakan komunitas yang spesifik, memberikan keyakinan pada janji yang disampaikan akan ditepati.

3. Kualitas usability

Kualitas usability meliputi kemudahan website untuk dipelajari, kemudahan untuk dimengerti, kemudahan untuk ditelusuri, kemudahan untuk digunakan, kemenarikan website, interface yang menyenangkan, memiliki kompetensi yang baik dan memberikan pengalaman baru yang menyenangkan.

\section{Importance Performance Analysis}

IPA diperkenalkan oleh Martilla dan James. Menurutnya metode ini telah mampu menunjukkan kemampuan untuk menyediakan manajerial pelayanan dengan informasi yang berharga untuk pengukuran kepuasan keduanya dan alokasi sumber daya yang efisien di dalam format yang sesuai dengan mudah (Baiti et al., 2017; Magal \& Levenburg, 2005).

Pendekatan IPA didasari oleh dua kepuasan, yaitu kepentingan (importance) dari sebuah produk atau jasa dan kinerja (performance) dalam memberikan layanan. Hal ini berarti bila kinerja masih dianggap jauh di bawah kepentingan maka dikatakan pengguna belum merasa namun bila kinerja sudah berada diatas angka kepentingan pengguna maka dapat dikatakan pengguna merasa puas dengan produk atau jasa yang diberikan (Mohebifar, Hasani, Barikani, \& Rafiei, 2016; Wahyudi et al., 2017).

Selanjutnya hasil analisa kepentingan dan kinerja dapat digambarkan ke dalam diagram kartesius IPA. Diagram kartesius IPA terdiri dari sumbu $x$ yang merepresentasikan tingka kinerja dan sumbu $y$ merepresentasikan tingkat kepentingan. Dalam Gambar 2 terdapat perpotongan sumbu $x$ dan sumbu $y$ dan menghasilkan 4 kuadran didalamnya, yaitu kuadran A (concentrate here), kuadran B (keep up 
the good work), kuadran C (low priority), dan kuadran D (possible overkill) (Saputra et al., 2018).

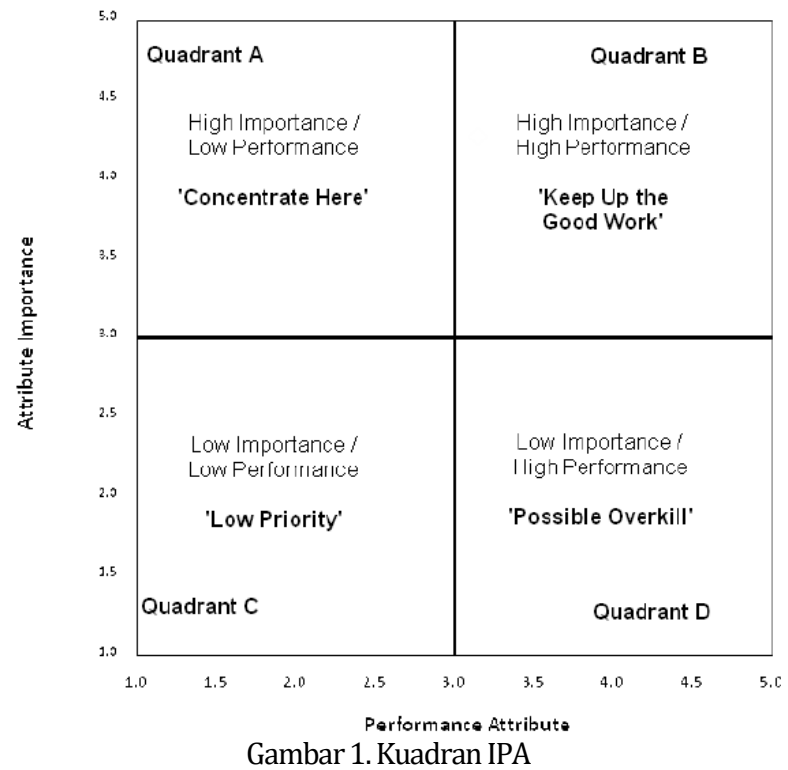

\section{HASIL DAN PEMBAHASAN}

Penelitian ini berfokus pada evaluasi kualitas layanan berdasarkan pada kepuasan pengguna dan kinerja layanan serta harapan pengguna. Pengguna dalam studi kasus ini yaitu mahasiswa Teknik Infromatika yang pernah mengakses website SIMANTA PKN UMM. Setelah dilakukan analisa kualitas dan kebutuhan pengguna dengan cara penyebaran kuisioner dengan variable yang ada pada metode Webqual 4.0 dengan pengukuran berdasarkan metode analisa IPA maka nantinya akan didapatkan sebuah hasil berupa dokumen saran perbaikan website.

\section{Analisis Data}

Tahapan analisa data yang dilakukan adalah sebagai berikut (Ong \& Pambudi, 2014):

1. Tahap Pertama yaitu menghitung tingkat kesesuaian antara tingkat kepentingan dan tingkat kinerja kualitas atribut-atribut yang diteliti. Rumus tingkat kesesuaian yang digunakan:

$$
T K_{i}=\frac{x_{i}}{y_{i}} \times 100 \%
$$

Keterangan :

$T K_{i}$ : tingkat kesesuaian

$x_{i} \quad$ : skor penilaian kinerja

$y_{i}$ : skor penilaian kepentingan

2. Tahap kedua adalah menghitung rata-rata penilaian tingkat kepentingan (importance) dan kinerja (performance) untuk setiap item atribut dengan rumus:

$$
\overline{X I}=\frac{\sum X I}{n} \quad \overline{Y I}=\frac{\sum Y I}{n}
$$

Keterangan :

$\overline{X I}$ :skor rata-rata tingkat kinerja layanan

$\overline{Y I}$ :skor rata-rata tingkat kepentingan terhadap layanan

$n$ :jumlah responden

3. Tahap terakhir yaitu menghitung rata-rata penilaian tingkat kepentingan (importance) dan kinerja (performance) untuk keseluruhan atribut dengan rumus:

$$
\overline{\overline{X I}}=\frac{\sum \overline{X I}}{k} \quad \overline{\overline{Y I}}=\frac{\sum \overline{Y I}}{k}
$$

Keterangan :

$\overline{\overline{X I}}$ : rata-rata skor tingkat kinerja produk seluruh faktor atau atribut

$\overline{\overline{Y I}}$ : rata-rata tingkat kepentingan seluruh atribut yang mempengaruhi kepuasan konsumen

$k$ : banyaknya atribut yang dapat mempengaruhi kepuasan konsumen

\section{Hasil Analisis}

Webqual merupakan metode pengukuran kualitas website yang berdasarkan pada persepsi pengguna. Metode ini dikombinasikan dengan metode analisis IPA untuk mengukur kepuasan pengguna terhadap sebuah barang maupun jasa yang ditawarnakan. Analisis didasari oleh dua kepuasan, yaitu kepentingan (importance) dari sebuah produk maupun jasa dan kinerja (performance) dalam memberikan layanan. Dapat diartikan bila kinerja masih dianggap jauh di bawah kepentingan maka dikatakan pengguna belum merasa namun bila kinerja sudah berada di atas angka kepentingan pengguna maka dapat dikatakan pengguna merasa puas dengan produk maupun jasa yang diberikan. Berikut merupakan hasil dari penelitian yang dilakukan $(\mathrm{Wu}$, Lee, Cheng, \& Tasi, 2012) :

1. Kuadran A (concentrate here)

Nilai tingkat kepentingan yang tinggi namun tingkat kinerja rendah. Artinya dibutuhkan perhatian untuk dilakukan perbaikan serta peningkatan dari atribut yang dianggap kurang. Layanan di kuadran ini menjadi prioritas utama dalam meningkatkan kualitas layanan. Menurut hasil penelitian didapatkan bahwa ada dua atribut yang perlu menjadi prioritas perbaikan yaitu tentang atribut informasi yang disajikan website SIMANTA PKN UMM relevan serta informasi yang disajikan website SIMANTA PKN UMM sesuai dengan format yang ada. Menurut pengguna kedua atribut tersebut belum sesuai dengan kebutuhan pengguna dan kinerja yang diberikan layanan masih kurang.

2. Kuadran B (keep up the good work)

Nilai tingkat kepentingan yang tinggi namun tingkat kinerja tinggi. Artinya memiliki kesempatan untuk mempertahankan atribut yang memiliki kelebihan. Layanan di kuadran ini dianggap penting oleh pengguna sehingga wajib dipertahankan. Pada kuadran ini atribut nomor A1, A2, A3, A7, A10, A14, 
dan A17 dapat dipertahankan keberadaannya karena kinerja layanan sudah sesuai dengan kebutuhan pengguna.

3. Kuadran C (low priority)

Nilai tingkat kepentingan namun tingkat kinerja sama rendahnya. Artinya pada kuadran ini menunjukan beberapa aspek yang kurang berdampak penting bagi pengguna. Terdapat atribut yang merupkan priorita rendah sehingga keberadaannya dapat diabaikan. Hasil penelitan menyatakan bahwa atribut dengan kode A4, A5, A8, A11, A13, A15, dan A16 dapat diabaikan keberadaannya karena tidak mempengaruhi kebutuhan pengguna dan kinerja layanan.

4. Kuadran D (possible overkill)

Nilai tingkat kepentingan yang rendah dan tingkat kinerja yang tinggi. Artinya terdapat atribut yang memiliki kinerja dengan sumber daya berlebih dan harus dikerahkan untuk atribut yang dianggap kurang seperti pada kudran A dan kuadran B. pada penelitian ini atribut yang terdapat pada kuadran ini hanya satu atribut yaitu atribut tentang website SIMANTA PKN UMM memberikan pengalaman positif.

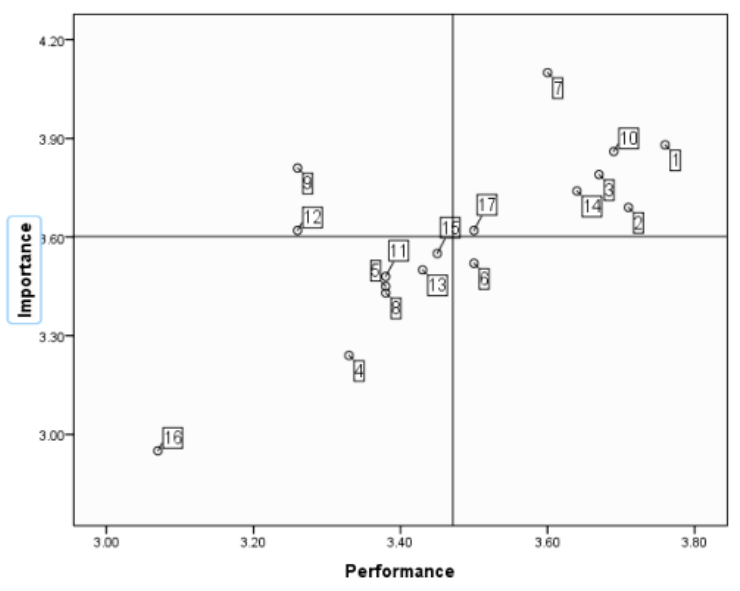

Gambar 2.Hasil Kuadran IPA

\begin{tabular}{|c|c|}
\hline $\begin{array}{c}\text { Kuadran I } \\
\text { Prioritas Utama } \\
\text { (Concentrate Here) } \\
\text { Setelah dilakukan analisis terdapat } \\
\text { beberapa atribut di Kuadran ini } \\
\text { yaitu atribut nomor } 9 \text { dan } 12\end{array}$ & $\begin{array}{c}\text { Kuadran II } \\
\text { Pertahankan Prestasi } \\
\text { (Keep Up The Good Work) } \\
\text { Setelah dilakukan analisis terdapat } \\
\text { beberapa atribut di Kuadran ini } \\
\text { yaitu atribut nomor 1,2,3,7,10,14, } \\
\text { dan } 17\end{array}$ \\
\hline $\begin{array}{c}\text { Kuadran III } \\
\text { Prioritas Rendah } \\
\text { (Low Priority) } \\
\text { Setelah dilakukan analisis terdapat } \\
\text { beberapa atribut di Kuadran ini } \\
\text { yaitu atributnomor 4,5,8,11,13,15, } \\
\text { dan } 16\end{array}$ & $\begin{array}{c}\begin{array}{c}\text { Kuadran IV } \\
\text { Berlebihan } \\
\text { (Possible Overkill) }\end{array} \\
\text { terdapat beberapa atribut di } \\
\text { Kuadran iniyaitu atributnomor } 6\end{array}$ \\
\hline
\end{tabular}

Gambar 3.Hasil Kuadran IPA(lanjutan)

\section{PENUTUP}

Kesimpulan yang akan didapatkan dari hasil penelitian ini diuraikan di hasil evaluasi yang telah dilakukan pada website SIMANTA PKN UMM menggunakan metode Webqual 4.0 dan IPA (Importance Performance Analysis) serta penyusunan dokumen saran perbaikan website. Dari hasil analisa yang dilakukan didapatkan fakta bahwa layanan SIMANTA PKN UMM perlu diadakan perbaikan pada beberapa atribut yang ada. Menurut data atribut yang perlu dilakukan perbaikan yaitu atribut dengan nomer 9, 6, dan 12 pada diagram kartesitus dengan nomer kode $A 9$, A6, dan A12. Dengan hasil evalusi yang ada, layanan SIMANTA PKN UMM perlu dilakukan perbaikan agar layanan dapat menghasil hasil atau informasi yang relevan dengan kegunaan layanan, dapat memberikan pengalaman yang positif kepada mahasiswa serta dapat menyajikan sebuah website dengan format yang sesuai dengan kebutuhan mahasiswa sebagai pengguna website.

\section{DAFTAR PUSTAKA}

Baiti, A. Al, Suprapto, \& Rachmadi, A. (2017). Pengukuran Kualitas Layanan Website Dinas Pendidikan Kota Malang Dengan Menggunakan Metode Webqual 4.0 dan IPA. Jurnal Pengembangan Teknologi Informasi Dan Ilmu Komputer, 1(9), 885-892. Retrieved from http://jptiik.ub.ac.id/index.php/jptiik/article/view/273

Barnes, S. J., \& Vidgen, R. T. (2003). Assessing the quality of a cross-national e-government Web site: a study of the forum on strategic management knowledge exchange. In System Sciences, 2003. Proceedings of the 36th Annual Hawaii International Conference on (p. 10-pp). IEEE.

Christian, T. L., \& Jaya, D. (2017). Impact of English online learning website quality to user satisfaction in Jakarta. In Information Management and Technology (ICIMTech), 2017 International Conference on (pp. 278283). IEEE.

Kadar, J. A., Napitupulu, D., \& Jati, R. K. (2017). Analysis of factors influencing the quality of intranet website based on WebQual approach case study in agency X. In Science in Information Technology (ICSITech), 2017 3rd International Conference on (pp. 526532). IEEE.

Magal, S. R., \& Levenburg, N. M. (2005). Using importance-performance analysis to evaluate e-business strategies among small businesses. In null (p. 176a). IEEE.

Mohebifar, R., Hasani, H., Barikani, A., \& Rafiei, S. 
(2016). Evaluating service quality from patients' perceptions: application of importance-performance analysis method. Osong Public Health and Research Perspectives, 7(4), 233-238.

Napitupulu, D. (2017). Analysis of Factors Affecting The Website Quality (Study Case: XYZ University). International Journal on Advanced Science, Engineering and Information Technology, 7(3), 792-798.

Ong, J. O., \& Pambudi, J. (2014). Analisis kepuasan pelanggan dengan Importance Performance Analysis di SBU Laboratory Cibitung PT Sucofindo (Persero).J@ Ti Undip: Jurnal Teknik Industri, 9(1), 1-10.

Saputra, R. A., Suprapto, \& Rachmadi, A. (2018). Penilaian Kualitas Layanan E-Government Dengan Pendekatan Dimensi EGovqual dan Importance Performance Analysis (IPA) (Studi Kasus Pada Pemerintah Provinsi Nusa Tenggara Barat). Jurnal Pengembangan Teknologi Informasi Dan Ilmu Komputer, 2(5), 1794-1802.
Tsai, I.-C., \& Yeh, C.-H. (2015). Integrating ServQual and Importance-Performance Analysis for Assessing Smart Campus Service Quality: A Case Study of an English Training Programme in Vietnam. In Advanced Learning Technologies (ICALT), 2015 IEEE 15th International Conference on (pp. 436440). IEEE.

Wahyudi, S. E., Pinandito, A., \& Saputra, M. C. (2017). Penilaian Kualitas Website EGovernment Pejabat Pengelola Informasi dan Dokumentasi (PPID) dengan Dimensi eGovQual (Studi pada Dinas Komunikasi dan Informatika Pemerintah Kota Probolinggo), 1(2), 108-117.

Wu, C.-H., Lee, Y.-C., Cheng, Y.-C., \& Tasi, S.-B. (2012). The use of importance-performance analysis (IPA) in evaluating bank services. In Service Systems and Service Management (ICSSSM), 2012 9th International Conference on (pp. 654-657). IEEE. 


\section{LAMPIRAN}

Tabel 1. Hasil Tahap 1

\begin{tabular}{cccc}
\hline Atribut & Tingkat Kinerja & Tingkat Kepentingan & Tingkat Kesesuaian \\
\hline A1 & 158 & 163 & 96.93251534 \\
A2 & 156 & 155 & 100.6451613 \\
A3 & 154 & 159 & 96.85534591 \\
A4 & 140 & 136 & 102.9411765 \\
A5 & 142 & 145 & 97.93103448 \\
A6 & 147 & 148 & 99.32432432 \\
A7 & 151 & 172 & 87.79069767 \\
A8 & 142 & 144 & 98.61111111 \\
A9 & 137 & 160 & 85.625 \\
A10 & 155 & 162 & 95.67901235 \\
A11 & 142 & 146 & 97.26027397 \\
A12 & 137 & 152 & 90.13157895 \\
A13 & 144 & 147 & 97.95918367 \\
A14 & 153 & 157 & 97.4522293 \\
A15 & 145 & 149 & 97.31543624 \\
A16 & 129 & 124 & 104.0322581 \\
A17 & 147 & 152 & 96.71052632 \\
Jumlah & 2479 & 2571 & 96.42162583 \\
\hline
\end{tabular}

Tabel 2. Hasil Tahap 2

\begin{tabular}{lllll}
\hline Atribut & Tingkat Kinerja & Rata2 Kinerja & Tingkat Kepenti-ngan & Rata2 Kepentingan \\
\hline A1 & 158 & 3.761904762 & 163 & 3.880952381 \\
A2 & 156 & 3.714285714 & 155 & 3.69047619 \\
A3 & 154 & 3.666666667 & 159 & 3.785714286 \\
A4 & 140 & 3.333333333 & 136 & 3.238095238 \\
A5 & 142 & 3.380952381 & 145 & 3.452380952 \\
A6 & 147 & 3.5 & 148 & 3.523809524 \\
A7 & 151 & 3.595238095 & 172 & 4.095238095 \\
A8 & 142 & 3.380952381 & 144 & 3.428571429 \\
A9 & 137 & 3.261904762 & 160 & 3.80952381 \\
A10 & 155 & 3.69047619 & 162 & 3.857142857 \\
A11 & 142 & 3.380952381 & 146 & 3.476190476 \\
A12 & 137 & 3.261904762 & 152 & 3.619047619 \\
A13 & 144 & 3.428571429 & 147 & 3.5 \\
A14 & 153 & 3.642857143 & 157 & 3.738095238 \\
A15 & 145 & 3.452380952 & 149 & 3.547619048 \\
A16 & 129 & 3.071428571 & 124 & 2.952380952 \\
A17 & 147 & 3.5 & 152 & 3.619047619 \\
Jumlah & 2479 & 1.405328798 & 2571 & 1.457482993 \\
\hline
\end{tabular}

Tabel 3. Hasil Tahap Terakhir

\begin{tabular}{lll}
\hline Atribut & Rata2 Kinerja & Rata2 Kepentingan \\
\hline A1 & 3.761904762 & 3.880952381 \\
A2 & 3.714285714 & 3.69047619 \\
A3 & 3.666666667 & 3.785714286 \\
A4 & 3.333333333 & 3.238095238 \\
A5 & 3.380952381 & 3.452380952 \\
A6 & 3.5 & 3.523809524 \\
A7 & 3.595238095 & 4.095238095 \\
A8 & 3.380952381 & 3.428571429 \\
A9 & 3.261904762 & 3.80952381 \\
A10 & 3.69047619 & 3.857142857 \\
A11 & 3.380952381 & 3.476190476 \\
A12 & 3.261904762 & 3.619047619 \\
A13 & 3.428571429 & 3.5 \\
A14 & 3.642857143 & 3.738095238 \\
A15 & 3.452380952 & 3.547619048 \\
A16 & 3.071428571 & 2.952380952 \\
A17 & 3.5 & 3.619047619 \\
JUMLAH & 3.471988796 & 3.600840336 \\
\hline
\end{tabular}

